\title{
Appraisal of Thermo-adaptability among Tharparkar and Crossbred Cattle Calves
}

\author{
Bosco Jose ${ }^{1}$, Pranay Kumar Konda ${ }^{1}$, Manoj Kumar Tripathi ${ }^{1}$, Khan Sharun ${ }^{2}$, \\ Shyam Kumar ${ }^{3}$, Gyanendra Singh ${ }^{1}$, Mihir Sarkar ${ }^{1}$ and Puneet Kumar ${ }^{1 *}$
}

${ }^{1}$ ICAR-Indian Veterinary Research Institute, Physiology \& Climatology Division, ${ }^{2}$ ICARIndian Veterinary Research Institute, Surgery Division, ${ }^{3}$ ICAR-Indian Veterinary Research Institute, Pharmacology \& Toxicology Division, Izatnagar, Bareilly, Uttar Pradesh-243122, India

*Corresponding author

\section{A B S T R A C T}

\begin{tabular}{l} 
Keyw or d s \\
Thermo- \\
adaptability, \\
Tharparkar and \\
Crossbred Cattle \\
\hline Article Info \\
\hline $\begin{array}{l}\text { Accepted: } \\
12 \text { October } 2020 \\
\text { Available Online: } \\
10 \text { November } 2020\end{array}$ \\
\hline
\end{tabular}

\section{Introduction}

The climate change is pertinent and its impact on the animal and human population is tremendous, directly threatens food security of all living beings. The decreased availability of forages, feed intake and feed conversion efficiency in domestic animals and the increased ingestion three times will be the major impacts of climate change (RojasDowning et al., 2017). The production parameters like milk and meat productivity have been adversely affected by the extreme
The appraisal of thermo-adaptability among two calf breeds in the controlled environment was the objective of this study. The first group was Tharparkar and second one was crossbred (Hariana; 25 and 50\% and Exotic; 50 and 75\%) calves. The investigative period consists of 7 days acclimatization period, and 21 days of thermal exposure at control $\left(25^{\circ} \mathrm{C}\right)$, moderate $\left(31^{\circ} \mathrm{C}\right)$ and severe $\left(37^{\circ} \mathrm{C}\right)$ heat stress (6 hrs. per day). There had 9-10 days recovery period across each exposure. During the investigation period, the blood was collected on 1st, 6th, 11th, 16th, 21 st day. The DMI of both breeds decreased in $31^{\circ} \mathrm{Cand} 37^{\circ} \mathrm{C}$ of heat exposure and increase in water intake was relatively more in Crossbred than Tharparkar calves. Also, non-significant variation (P.0.05) in relative expression of IL-1 $\beta$ and IL10 among Crossbred and Tharparkar calves was recorded. 
Homeostasis is the mechanisms to maintain constant internal milieu of the homeotherms. The physiological, behavioral, hormonal and immune mechanisms aid to compensate the change in the same parameters. The thermoadaptability of the animal keeps the equilibrium between heat gain and heat loss from the body and it depends on the ambient temperature (Marai and Haeeb, 2010). The thermal stress stimulates rostral cooling center of the brain and further stimulates satiety center, inhibits lateral appetite center. It causes reduction in feed intake and productivity of animals (Albright and Alliston 1972). The thermal stress influences the expressions of various genes including heat shock proteins and other immunologically relevant genes (Sonna et al., 2002). Some of the cytokines secreted from leukocytes have functions as growth factors, proinflammatory and anti-inflammatory factors Van Miert (1995). The pro-inflammatory cytokines are responsible for the febrile reactions and other inflammatory responses in the body. One of them is IL-1 $\beta$ and showed a positive correlation with body temperature in humans (Chang DM, 1993). The Interleukin 10 (IL10), an anti-inflammatory cytokines that defends the inflammatory reactions effectively (Kuhn et al., 1993; Sabat et al., 2010). The relations between temperature and IL10 and TLR2 were discussed by various authors in different species (Thompson et al., 2014).

Various studies underscored that indigenous animals perform better than crossbred/exotic animals during heat stress. Thermoadaptability of the indigenous animals should be screened and the selection and breeding of climate resilient animals should be followed to defend the changing climate. With limited parameters into consideration, this study evaluated the thermo-adaptability between two Indian dual-purpose cattle breeds.

\section{Materials and Methods}

This study was done at the $\mathrm{P} \& \mathrm{C}$ division, IVRI, Uttar Pradesh, India, located at the latitude of $28^{\circ} 22^{\prime} \mathrm{N}$ and $79^{\circ} 24^{\prime} \mathrm{E}$. This study was conducted on male cattle calves in2 groups, aged 6-8 months inside a psychrometric chamber. The first group consisted6 Tharparkar calves and other group consisted of 6 crossbred (Hariana inheritance; $25 \& 50 \%$ and Exotic inheritance; 50 \& $75 \%$ ) calves. The calves were maintained inside a psychrometric chamber under isomanagerial conditions. The temperature humidity index (THI) was used to evaluate the thermal stress on animals (McDowells, 1976).

\section{Experimental design}

The same group of calves was exposed for 21 days each to $25^{\circ} \mathrm{C}$ (comfort zone), moderate $\left(31^{\circ} \mathrm{C}\right)$ and severe $\left(37^{\circ} \mathrm{C}\right)$ heat stress. The animals were acclimatized and, there were 10 days of recovery between each temperature exposure. The calves were exposed to heat for 6 hours a day, preferably between 9am to 3 $\mathrm{pm}$. The feed and water provided, and the dry matter and water intake were measured. The blood collection was done on $1^{\text {st }}, 11^{\text {th }}$ and $21^{\text {st }}$ day of thermal stress for the evaluation of immunological gene expression.

The PBMCs were isolated using Histopaque, with density gradient centrifugation. Briefly, the equal volume of anticoagulant added blood was layered over the histopaque. Then centrifugation was done at the speed of $250 \mathrm{~g}$ for half an hour. Then isolated the white layer from the junction and washed twice in PBS. Followed by the isolation of the total RNA was done at the trizol method as manufacturers method. The cDNAs were synthesized using iScript cDNA synthesis kit from Biorad laboratories and the relative expression of immunological relevant genes like IL1 $\beta$ and IL10 were measured using RT- 
PCR. The primers used in the study were tabulated in table. 1. The relative expression of particular mRNA was estimated by Pfaffl method (2001).

\section{Results and Discussion}

\section{Water intake}

The Mean \pm SEM of Water intake (Litres/day) of Crossbred and Tharparkar calves during control $\left(25^{\circ} \mathrm{C}\right)$, moderate $\left(31^{\circ} \mathrm{C}\right)$ and severe $\left(37^{\circ} \mathrm{C}\right)$ heat stress was showed in table 2 and Fig. 1. The Water intake (Litres/day) of Crossbred calves during $25^{\circ} \mathrm{C}$ was $4.12 \pm 0.05$. The Water intake (Litres/day) increased to $6.41 \pm 18$ during $31^{\circ} \mathrm{C}$, and it further increased to $8.39 \pm 0.29$ during $37^{\circ} \mathrm{C}$ in Crossbred calves. In case of Tharparkar calves Water intake (Litres/day) during $25^{\circ} \mathrm{C}$ was $3.98 \pm .06$. The Water intake (Litres/day) increased to $6.41 \pm .18 \mathrm{Kg}$ during $31^{\circ} \mathrm{C}$, and it further increased to $7.71 \pm 0.25$ through the severe heat stress $\left(37^{\circ} \mathrm{C}\right)$ in Tharparkar calves.

Table.1 Primer sequences used and resulting fragment size

\begin{tabular}{|l|l|l|l|l|}
\hline Gene & Sequence of nucleotide & $\begin{array}{l}\text { Fragment } \\
\text { size (bp) }\end{array}$ & $\begin{array}{l}\text { Annealing } \\
\text { temperature }\end{array}$ & EMBL/reference \\
\hline IL 1及 & $\begin{array}{l}\text { For:5'-CAAGGAGAGGAAAGAGACATG- 3' } \\
\text { Rev: 5'-AGAAGTGCTGATGTACCA - 3' }\end{array}$ & 236 & $60^{\circ} \mathrm{C}$ & Konnai et al 2003 \\
\hline IL10 & $\begin{array}{l}\text { For: 5'- TGCTGGATGACTTTAAGGGAGGG-3' } \\
\text { Rev: 5'-CAGAAAGCGATGACA-3' }\end{array}$ & 186 & $60^{\circ} \mathrm{C}$ & Konnai et al 2003 \\
\hline GAPDH & $\begin{array}{l}\text { For: 5'-CTTTGGCATCGTGGAGGGACTTA-3' } \\
\text { Rev:5'-CCAGCCCCAGCATCGAAGGTAGA-3' }\end{array}$ & 82 & $60^{\circ} \mathrm{C}$ & U85042.1 \\
\hline
\end{tabular}

Table.2 The Mean \pm SEM of Water intake (Litres/day) of Crossbred and Tharparkar calves during control $\left(25^{\circ} \mathrm{C}\right)$, moderate $\left(31^{\circ} \mathrm{C}\right)$ and severe $\left(37^{\circ} \mathrm{C}\right)$ heat stress

\begin{tabular}{|r|l|l|}
\hline \multicolumn{1}{|c|}{ Temperature } & Group of animals & Water Intake (Litres/Day) \\
\hline $\mathbf{2 5}^{\circ} \mathbf{C}$ & CB & $4.12 \pm 0.05$ \\
\hline & THARPARKAR & $3.98 \pm 0.06$ \\
\hline $\mathbf{3 1}^{\circ} \mathbf{C}$ & CB & $6.41 \pm 0.18$ \\
\hline & THARPARKAR & $6.35 \pm 0.16$ \\
\hline $\mathbf{3 7}^{\circ} \mathbf{C}$ & CB & $8.39 \pm 0.29$ \\
\hline & THARPARKAR & $7.71 \pm 0.25$ \\
\hline
\end{tabular}

Table.3 The Mean \pm SEM of DMI (Kg/Whole body weight) of Crossbred and Tharparkar calves during control $\left(25^{\circ} \mathrm{C}\right)$, moderate $\left(31^{\circ} \mathrm{C}\right)$ and severe $\left(37^{\circ} \mathrm{C}\right)$ heat stress period.

\begin{tabular}{|r|l|l|}
\hline Temperature & Group of animals & DMI intake \\
\hline $\mathbf{2 5}^{\circ} \mathbf{C}$ & CB & $2.7 \pm .01$ \\
\hline & THARPARKAR & $2.65 \pm .03$ \\
\hline $\mathbf{3 1}^{\circ} \mathbf{C}$ & CB & $2.55 \pm .02$ \\
\hline & THARPARKAR & $2.58 \pm .01$ \\
\hline $\mathbf{3 7}^{\circ} \mathbf{C}$ & CB & $2.51 \pm .02$ \\
\hline & THARPARKAR & $2.57 \pm .02$ \\
\hline
\end{tabular}


Fig.1 Water intake of Crossbred and Tharparkar calves on exposure to $25^{\circ} \mathrm{C}$ (control), $31^{\circ} \mathrm{C}$ and $37^{\circ} \mathrm{C}$ in psychrometric chamber

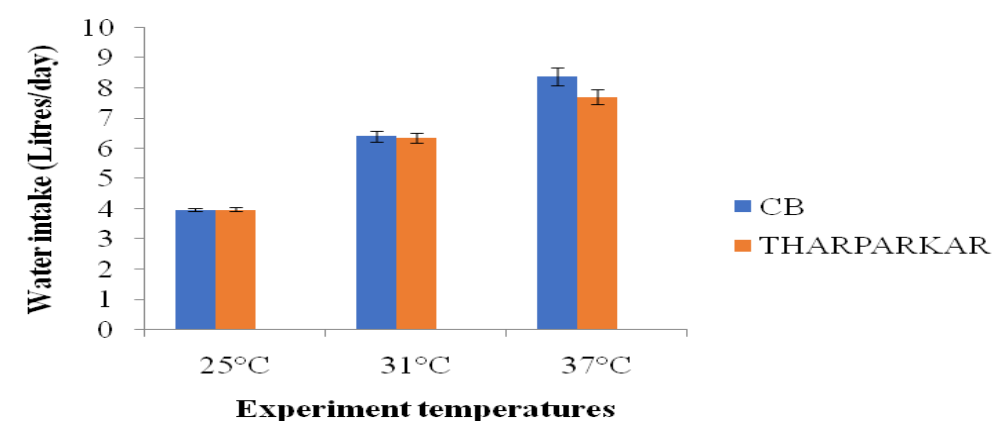

Fig.2 DMI of Crossbred and Tharparkar calves on exposure to $25^{\circ} \mathrm{C}$ (control), $31^{\circ} \mathrm{C}$ and $37^{\circ} \mathrm{C}$ in psychrometric chamber

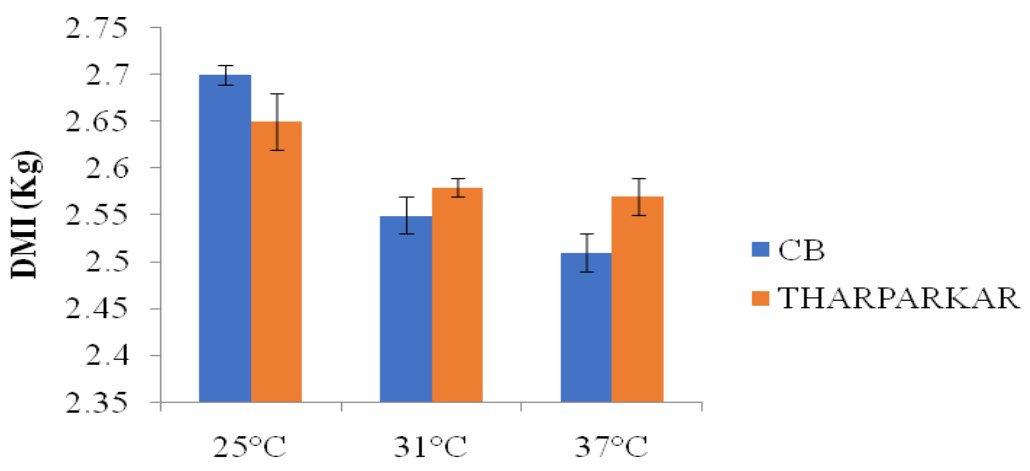

Experiment temperatures

Fig.3 a) Effect of moderate heat stress $\left(31^{\circ} \mathrm{C}\right)$ on IL1 $\beta$ relative expression, b) $37^{\circ} \mathrm{C}$ on on IL1 $\beta$ relative expression c) $31^{\circ} \mathrm{C}$ on IL10 relative expression, d) $37^{\circ} \mathrm{C}$ on IL10 relative expression among Crossbred and Tharparkar calves
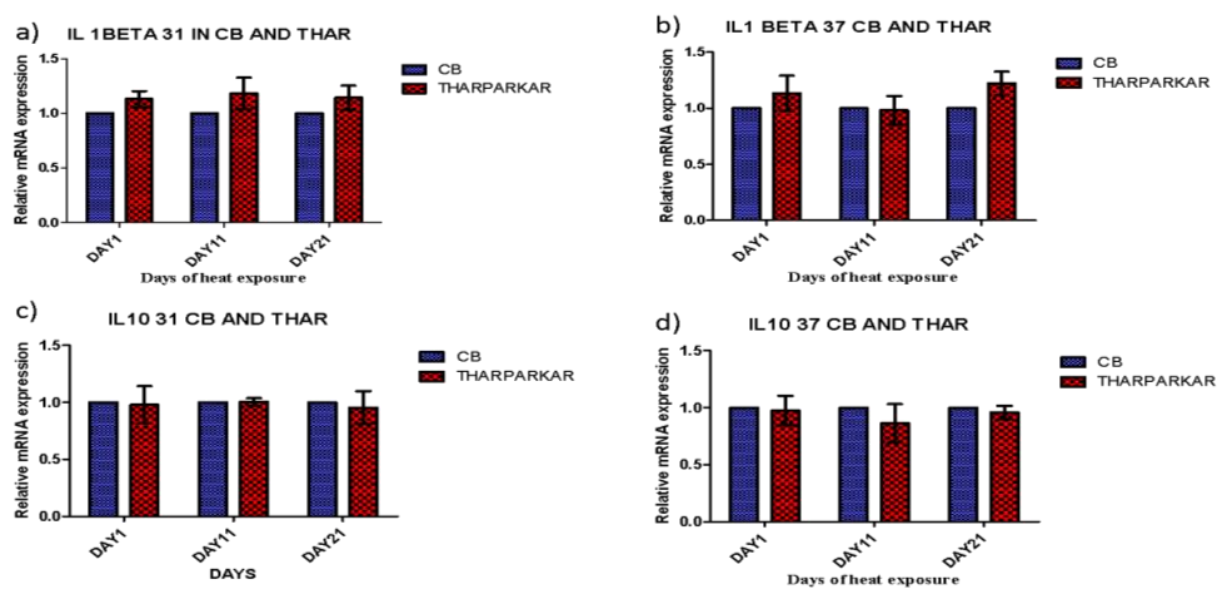


\section{Feed intake}

The Mean \pm SEM of DMI $(\mathrm{Kg} /$ Whole body weight) of Crossbred and Tharparkar calves during control $\left(25^{\circ} \mathrm{C}\right)$, moderate $\left(31^{\circ} \mathrm{C}\right)$ and severe $\left(37^{\circ} \mathrm{C}\right)$ heat stress was showed in th table 3 and Fig. 2. The DMI of Crossbred calves during $25^{\circ} \mathrm{C}$ was $2.7 \pm .01 \mathrm{Kg}$. The DMI reduced to $2.55 \pm .02 \mathrm{Kg}$ during $31^{\circ} \mathrm{C}$, and it further reduced to $2.51 \pm .02 \mathrm{Kg}$ during $37^{\circ} \mathrm{C}$ in crossbred calves. In case of Tharparkar calves DMI during $25^{\circ} \mathrm{C}$ was $2.65 \pm .03 \mathrm{Kg}$ and it reduced to $2.58 \pm .01 \mathrm{Kg}$ during $31^{\circ} \mathrm{C}$, again it further reduced to $2.57 \pm .02 \mathrm{Kg}$ during $37^{\circ} \mathrm{C}$.

\section{Interleukins}

During $31^{\circ} \mathrm{C}$, IL1 $\beta$ expression was high in Tharparkar than Crossbred calves in all investigation period, albeit non-significant (P>0.05). During $37^{\circ} \mathrm{C}$, initially, IL $1 \beta$ was high in Tharparkar calves, later the expression was comparable among breeds. Again, in the end of study, the expression was increased in Tharparkar calves in comparison to Crossbred (Fig. 3).

During $31^{\circ} \mathrm{C}$, the expression of IL10 was similar among breeds. At $37^{\circ} \mathrm{C}$, a slight decrease of IL10 was noted in Tharparkar than Crossbred calves, though it was nonsignificant $(\mathrm{P}>0.05)$.

\section{Water intake}

A positive correlation was observed between the increase in environment temperature and of water intake (Marai and Haeeb, 2010). In present study, the water intake of Crossbred calves increased from $4.12 \pm 0.05$ (Litres/day) at $25^{\circ} \mathrm{C}$ to $8.39 \pm 0.29$ (Litres/day) at $37^{\circ} \mathrm{C}$ heat exposure. The water intake of Tharparkar calves increased from $3.98 \pm 0.06$ (Litres/day) at $25^{\circ} \mathrm{C}$ to $7.71 \pm 0.25$ (Litres/day) at $37^{\circ} \mathrm{C}$ heat exposure. The relative increase was more in
Crossbred calves. Similarly, Beatty et al., (2006) observed significant increase $(\mathrm{p}<0.001)$ in daily water intake during thermally stressful period in Bos indicus cattle. The increase in water intake is due to increase in osmoconcentration as a result of heat stress. It activates hypothalamic thirst center leading to higher water intake in the acclimating cattle to heat stress (Wankar et al., 2014). Thermal sensors at cerebral levels, and thirst sensors and sensors regulating release of vasopressin are interconnected at the hypothalamic level and thermoregulatory mechanisms are compensated to the water balance of the animal (Baker, 1982).

\section{Feed intake}

The regulatory responses to heat stress in animal include declined feed intake (Silanikove, 1992), enhanced respiration rates (Yousef, 1985), low heart rates and sweating (Blazquez et al., 1994), reduced milk production (Albright and Alliston, 1972; Lu, 1989). In present study, the DMI of Crossbred calves decreased from $2.7 \pm .01 \mathrm{Kg}$ at $25^{\circ} \mathrm{C}$ to $2.51 \pm .02 \mathrm{Kg}$ at $37^{\circ} \mathrm{C}$ heat exposure. In case of Tharparkar calves DMI decreased from $2.65 \pm .03 \mathrm{Kg}$ at $25^{\circ} \mathrm{C}$ to $2.57 \pm .02 \mathrm{Kg}$ at $37^{\circ} \mathrm{C}$ heat exposure, means that the decrease in DMI of Tharparkar calves was less than Crossbred calves. It may due to Heat stress leads to the rostral cooling center of the hypothalamus to stimulate the medial satiety center which inhibits the lateral appetite center, and thus reduced dietary intake, therefore increasing environmental temperature and rising rectal temperature above critical thresholds are related to decrease in the dry matter intake (DMI) (Albright and Alliston, 1972). The DMI declineed in an adaptive response to thermal stress as enhanced ambient temperature reduces the digestive tract motility, ruminal contractions and decreases appetite in ruminants (Yadav, 2012). 


\section{Interleukins}

Interleukin-1 $\beta$ (IL-1 $\beta$ ), a pro-inflammatory cytokine that is crucial for defence responses to any infection (C.A. Dinarello, 1996). Positive correlations were demonstrated between the body temperature and the level of IL-1 $\beta$ in human (Chang DM, 1993). In one study reported that as temperature increased an increase in IL-1 $\beta$ was observed in calves. In our observation of relative expression of IL-1 $\beta$ was more in Tharparkar calves than Crossbred calves at moderate $\left(31^{\circ} \mathrm{C}\right)$ heat stress, but it was nonsignificant $(\mathrm{P}>0.05)$. Similarly, IL10 expression was comparable between two breeds at moderate and severe heat stress. In this study, there was no significant variation (P.0.05) in relative expression of IL-1 $\beta$ and IL10 between Crossbred and Tharparkar calves. In our study, cytokines not showed any pattern of change in different experimental temperatures.

\section{Acknowledgements}

We thank Head of P \& C Division, and Director of IVRI for providing necessary facilities to do this research work.

\section{References}

Albright, J.L. and Alliston, C.W., 1971. Effects of varying the environment upon the performance of dairy cattle. Journal of Animal Science, 32(3), pp. 566-577.

Baker, M.A., 1982. Brain cooling in endotherms in heat and exercise. Annual Review of Physiology, 44(1), pp.85-85.

Beatty, D.T., Barnes, A., Taylor, E., Pethick, D., McCarthy, M. and Maloney, S.K., 2006. Physiological responses of Bos taurus and Bos indicus cattle to prolonged, continuous heat and humidity. Journal of animal science, 84(4), pp. 972-985.

Blazquez, N.B., Long, S.E., Mayhew, T.M., Perry, G.C., Prescott, N.J. and Wathes, C., 1994. Rate of discharge and morphology of sweat glands in the perineal, lumbodorsal and scrotal skin of cattle. Research in veterinary science, 57(3), pp. 277-284.

Chang, D.M., 1993. The role of cytokines in heat stroke. Immunological investigations, 22(8), pp. 553-561.

Dinarello, C.A., 1996. Biologic basis for interleukin-1 in disease.

Henry, B., Charmley, E., Eckard, R., Gaughan, J.B. and Hegarty, R., 2012. Livestock production in a changing climate: adaptation and mitigation research in Australia. Crop and Pasture Science, 63(3), pp.191-202.

Konnai, S., Usui, T., Ohashi, K. and Onuma, M., 2003. The rapid quantitative analysis of bovine cytokine genes by real-time RT-PCR. Veterinary microbiology, 94(4), pp.283-294.

Kühn, R., Löhler, J., Rennick, D., Rajewsky, K. and Müller, W., 1993. Interleukin10-deficient mice develop chronic enterocolitis. Cell, 75(2), pp.263-274.

Marai, I.F.M. and Haeeb, A.A.M., 2010. Buffalo's biological functions as affected by heat stress-A review. Livestock Science, 127(2-3), pp.89109.

McDowell, R. E., Hooven, N. W. and Camoens. J. K. 1976. Effects of climate on performance of Holsteins in first lactation. J. Dairy Sci. 59: 965973.

Nardone, A., Ronchi, B., Lacetera, N., Ranieri, M.S. and Bernabucci, U., 2010. Effects of climate changes on animal production and sustainability of livestock systems. Livestock Science, 130(1-3), pp. 57-69.

Pfaffl, M.W., 2001. A new mathematical 
model for relative quantification in real-time RT-PCR. Nucleic acids research, 29(9), pp.e45-e45.

Rojas-Downing, M.M., Nejadhashemi, A.P., Harrigan, T. and Woznicki, S.A., 2017. Climate change and livestock: Impacts, adaptation, and mitigation. Climate Risk Management, 16, pp.145-163.

Sabat, R., Grütz, G., Warszawska, K., Kirsch, S., Witte, E., Wolk, K. and Geginat, J., 2010. Biology of interleukin-10. Cytokine \& growth factor reviews, 21(5), pp.331-344.

Silanikove, N., 1992. Effects of water scarcity and hot environment on appetite and digestion in ruminants: a review. Livestock Production Science, 30(3), pp.175-194.

Sonna, L.A., Fujita, J., Gaffin, S.L. and Lilly, C.M., 2002. Invited review: effects of heat and cold stress on mammalian gene expression. Journal of applied physiology, 92(4), pp.1725-1742.

Thompson-Crispi, K., Atalla, H., Miglior, F. and Mallard, B.A., 2014. Bovine mastitis: frontiers in immunogenetics. Frontiers in Immunology, 5, p.493.

Thornton, P.K., van de Steeg, J., Notenbaert, A. and Herrero, M., 2009. The impacts of climate change on livestock and livestock systems in developing countries: A review of what we know and what we need to know. Agricultural systems, 101(3), pp.113127.

Van Miert, A.S.J.P.A.M., 1995. Pro-inflammatory cytokines in a ruminant model: Pathophysiological, pharmacological, and therapeutic aspects. Veterinary Quarterly, 17(2), pp.41-50.

Venkateswarlu, B. and Rao, V.U.M., 2013. Climate change and its impact on Indian agriculture. Climate Change Modeling, Mitigation, and Adaptation, pp. 419-453.

Wankar, A.K., Singh, G. and Yadav, B., 2014. Thermoregulatory and adaptive responses of adult buffaloes (Bubalus bubalis) during hyperthermia: Physiological, behavioral, and metabolic approach. Vet world, 7(10), pp.825-30.

Yadav, B. 2012. Physio-biochemical responses and methane emission during thermal stress in cattle. M. V. Sc. Thesis, Deemed University, I. V. R. I. Izatnagar. India.

Yousef, M.K., 1985. Stress physiology in livestock. Volume I. Basic principles. CRC press.

\section{How to cite this article:}

Bosco Jose, Pranay Kumar Konda, Manoj Kumar Tripathi, Khan Sharun Shyam Kumar, Gyanendra Singh, Mihir Sarkar and Puneet Kumar. 2020. Appraisal of Thermo-adaptability among Tharparkar and Crossbred Cattle Calves. Int.J.Curr.Microbiol.App.Sci. 9(11): 15881594. doi: https://doi.org/10.20546/ijcmas.2020.911.188 